\title{
AUDITING OF PROJECTS FINANCED FROM EUROPEAN FUNDS FOR THE PROGRAMMING PERIODS 2007-2013 AND 2014-2020 AND FINANCIAL IMPACT OF IRREGULARITIES IN ROMANIA
}

\author{
Grosu Maria ${ }^{1}$ \\ Mihalciuc Camelia Cătălina²
}

DOI: https://doi.org/10.31410/ERAZ.S.P.2019.117

\begin{abstract}
In Romania, but also in other EU countries, the projects funded by European funds have a special regime for auditing. This study aims at a comparative approach to identifying the most frequent irregularities with financial impact of beneficiaries of European projects found during the 2007-2013 and 2014-2020 programming periods (until 2017). The analysis is based on the Reports published by the Romanian Court of Accounts for a period of eight years from 2010 to 2017, aiming at auditing the projects funded by seven Operational Programs (OP).
\end{abstract}

Keywords: Financial audit, external public audit, audit of operations, European funds.

\section{INTRODUCTION}

Tn Romania, since January 2014, it was considered that they can participate in the auditing of projects financed from European funds only auditors, active members of the Chamber of Financial Auditors of Romania (CFAR), according to the protocol signed between the Ministry of European Funds (MEF) and the body governing the audit profession at the national level, respectively CFAR [1]. In the context of the current regulations on the implementation of the Operational Programs (OP) 2014-2020, the independent financial audit of projects funded by European funds is no longer a compulsory activity, as is indicated in the Specific Guidelines for the Programs launched. As a result, the Collaboration Protocol concluded in 2014 has become obsolete and has therefore been terminated in May 2017 [2] by a number of specialists disputed. Given the conditions, auditing European projects remains the responsibility of the Audit Authority (AA) of the Court of Accounts of Romania (CAR).

The start of this research was given by the fact that the CAR report in 2014 [3] indicated that AA found irregularities of over 50 million Euro in the expenditure declared for settlement by the European Commission (EC) in 2013 by the entities in Romania which have benefited from non-reimbursable funding from the Structural and Cohesion Funds (SF and CF). In previous research [4], aimed at identifying significant systems considered most risky encountered the beneficiaries of funds in Romania by the AA in 2007-2013, and the identification of improvements on the line of legality and regularity of expenditure declared EC projects that were to be launched in 2014-2020, following the recommendations made by representatives of CAR.

This study continues research with a comparative approach on identifying the most frequent irregularities affecting the financial beneficiaries of European projects in Romania, recorded

Faculty of Economics and Business Administration, „Alexandru Ioan Cuza“ University of Iasi, Romania, Carol I Blvd., No. 22

2 Faculty of Economics and Public Administration, "Stefan cel Mare" University of Suceava, Romania, St. Universitatii, No. 13 
in both periods: 2007-2013 and 2014-2020 to highlight features seven OP. Fund allocations are divided into seven OPs for the 2007-2013 programming period, namely: the Regional Operational Program (ROP), financed by the European Regional Development Fund (ERDF); Sectoral Operational Program Increase of Economic Competitiveness (SOP IEC), financed by the ERDF; the Operational Program Technical Assistance (OPTA), financed by the ERDF; The Sectoral Operational Program Environment (SOP E), financed by the ERDF and the Cohesion Fund (CF); Sectoral Operational Program Transport (SOP T), financed by ERDF and CF; The Sectoral Operational Program Human Resources Development (SOP HRD), financed by the European Social Fund (ESF); Operational Program Administrative Capacity Development (OP ACD), funded by the ESF. For the 2014-2020 programming period, some OPs have different names.

According to European regulations for the 2007-2013 programming period, the deadline for eligibility of expenditure for projects financed through Structural and Cohesion in this period was 31.12.2015, which means that in terms of audit cannot do clear distinction of irregularities on the two programming periods, but their track changes over a period of eight years. In addition, for the 2014-2020 programming period, the study stops at 2017, the year for which data has been reported so far.

A further review of both the legal framework [5], [6] for auditing European funded projects, as well as national and international studies and research have been carried out on this issue topic in the last period.

\section{LITERATURE REVIEW}

About a legal, national, relative to compulsory auditing of projects financed by grants, can speak only in 2006 with the advent of the Practical Guide (February 2006) for contractual procedures related to Phare, Ispa and Sapard [7]. ISRS 4400 „,Settlement of agreed procedures for financial information" is the audit standard that does not involve the expression of an assurance, but only provides a report on the actual findings, on the basis of which the lender formulates its own conclusions [8], [9]. For the auditing of projects funded by European funds, both in the period 2007-2013 and as of 2014, CFAR members have followed and continue to observe the provisions contained in the concluded financing contracts. In the context of the current regulations on the implementation of the 2014-2020 OP, the independent financial audit of projects funded by European funds is no longer a compulsory activity, as is clear from the Specific Guidelines, which remains the responsibility of the AA within the CAR.

Concerning the studies and research carried out in connection with the auditing of projects funded by European funds, various points of view can be found in several papers, even covering the period 2014-2020 [10] - [13]. Other authors [14] are focusing on conducting studies on the involvement of active financial auditors in the area of related services to verify the expenses of European projects [15], namely the market concentration of these services in Romania, compared to the other auditor activities. There are authors [16] - [18] who have proposed Guidelines for documenting a mission to verify the amounts spent on Structural Fund projects. In the literature we also find concerns about the synthesis of the difficulties identified in the audit practice of projects funded by European funds [19], [20]. European non-reimbursable funds have also been a recovery measure for the countries of the European Union after the economic crisis of 2009, especially on the labor market. [21]. Other authors have studied the absorption of structural funds in Romania over the period 2007-2013 [22], [23]. 
Based on literature review, this study is focused on analysis of published reports CAR section covering audit of EU funded projects in the period 2010-2017 [24]. The aim is to identify, analyze and compare the most frequent irregularities found in the eligibility of project expenditure during this period in Romania. It is important to note that some expenditure declared and audited during 2014-2017 does not belong to the 2014-2020 programming period, which is an extension of the previous programming period.

\section{RESEARCH METHODOLOGY: POPULATION, SAMPLE, VARIABLES, DATA SOURCE, DATA ANALYSIS METHODS}

For comparative study on the financial impact of irregularities resulting from the audit of EU funded projects during the 2007-2013 and 2014-2020, the total population programs funded by grants, were selected seven projects included in OP financed of the Structural Funds (FS) and the Cohesion Fund (CF), which were mentioned above. For the programming period 2014-2020, some OP have changed names, but to ensure comparability, were using the same statistical unit.

The sample analyzed consists of over 7000 projects implemented in the two programming periods: 2007-2013 and 2014-2020, included in the seven OP, which represent about $30 \%$ of the entire population. But analysis was performed on the $\mathrm{PO}$ rather than individual projects.

The variables analyzed after collecting the basic data are shown in the table below.

Table 1: Variables

\begin{tabular}{|l|l|}
\hline Symbol & Explanation \\
\hline DE_2007_2013 & Declared Expenses EC 2007-2013 (Euro) \\
\hline DE_2014_2017 & Declared Expenses EC 2014-2017 (Euro) \\
\hline AE_2007_2013 & Audited Expenses 2007-2013 (Euro) \\
\hline AE_2014_2017 & Audited Expenses 2014-2017 (Euro) \\
\hline AE/DE_2007_2013 & Share of Audited Expenses in Declared Expenses 2007-2013 (\%) \\
\hline AE/DE_2014_2017 & Share of Audited Expenses in Declared Expenses 2014-2017 (\%) \\
\hline FIIAE_2007_2013 & Total Financial Impact of Irregularities in the Audited Expenses 2007-2013 (Euro) \\
\hline FIIAE_2014_2017 & Total Financial Impact of Irregularities in the Audited Expenses 2014-2017 (Euro) \\
\hline IF/TI_2007_2013 & Share of Irregularities Found in Total Irregularities 2007-2013(\%) \\
\hline IF/TI_2014_2017 & Share of Irregularities Found in Total Irregularities 2014-2017(\%) \\
\hline IPP/TI_2007_2013 & Share of Irregularities in Public Procurement in Total Irregularities 2007-2013 (\%) \\
\hline IPP/TI_2014_2017 & Share of Irregularities in Public Procurement in Total Irregularities 2014-2017 (\%) \\
\hline IOIE/TI_2007_2013 & $\begin{array}{l}\text { Share of Irregularities in Other Ineligible Expenses in Total Irregularities 2007- } \\
\text { 2013(\%) }\end{array}$ \\
\hline IOIE/TI_2014_2017 & $\begin{array}{l}\text { Share of Irregularities in Other Ineligible Expenses in Total Irregularities 2007-2013 } \\
\text { 2014-2017(\%) }\end{array}$ \\
\hline IF/AE_2007_2013 & Share of Irregularities Found in Audited Expenses 2007-2013 (\%) \\
\hline IF/AE_2014_2017 & Share of Irregularities Found in Audited Expenses 2014-2017 (\%) \\
\hline IF/DE_20072013 & Share of Irregularities Found in Declared Expenses 2007-2013 (\%) \\
\hline IF/DE_2014_2017 & Share of Irregularities Found in Declared Expenses 2014-2017 (\%) \\
\hline Sour_ew
\end{tabular}

Source: own projection

For the 2007-2013 period, the variables have been analyzed since 2010, the year in which the data were available, but also because the projects were launched, approved and audited after the opening year of the programming period. For the 2014-2020 programming period, the last year surveyed is 2017, for the following periods not yet reported.

Data collection was based on bibliographic documentation using CAR reports published for each of the eight years examined related programming periods 2007-2013 and 2014-2020. It is 
important to note that in this study the data that represented the results of AA were collected as a result of the audit of each OP for the 2007-2013 and 2014-2020 programming periods but with the analysis of the year 2017. According to the Council Regulation (EC) no. 1083/2006, AA must ensure that audit missions are carried out in order to ensure that the management and control systems of the OP function effectively (system audit) and audit missions of operations on the basis of an appropriate sample in order to obtain an assurance that all declared costs are fair and legal. In this study, we analyzed ten CAR reports published between 2008-2017 (2007 paired with 2008), following the results obtained from the audit operations, not audit system, but analysis was performed in final eight datasets (on the grounds that some years were engaged and were found only descriptive information).

For data analysis, it has recourse to quantitative methods, such as: systematization (grouping, tabulation, graph) and the comparison using the primary indicators, and relative derivatives, as can be observed from the presentation of the variables in the Table 1. Also, for a synoptic presentation of variables and statistical units, we Analyzed the Main Components (AMC) as a descriptive method of multidimensional analysis of data [25], [26] which is applied in the study of correlations between numerical variables. Specifically, it was considered highlighting statistical links between variables taken into account, on the one hand, and the similarities and differences between statistical units, i.e. seven OP envisaged by variables recorded. Below we present the final results and their interpretation using systematization using graphical tools.

\section{RESULTS AND DISCUSSIONS}

In Romania, AA is the one that informs the European Commission, the Parliament of Romania, but also the public opinion on how to use the non-reimbursable funds, as well as on the main deficiencies found. The auditor's opinion is based on all audit work and an assessment of the generality of the error by comparing it with the materiality threshold established in the audit planning. In all CAR reports, we find an acceptable level of materiality of $2 \%$ of the declared expenditure. Beyond this threshold, the error rate is considered to be significant.

The results of processing are summarized in the charts below. Thus, starting from the variables included in the Table 1, the first examines the share of expenditure audited by AA in total expenditure declared EC. For the two periods analyzed, on the total OP, the percentage of expenditure audited in the total expenditure declared exceeds by at least $30 \%$ for the two periods considered. We present in Figure 1 the weight of Audited Expenses (AE) in Declared Expenses (DE). On the OP and periods, it can be seen from Figure 1 that the largest share of the audited expenditures in the total expenditures declared in the projects is owned by SOP T, over $70 \%$, followed by the OPTA for the period 2007-2013 and the OPTA over 70\%, followed by ACD, for the period 2014-2017. The lowest weights of the expenditure audited in the declared expenditure are held by the SOP HRD, even less than $10 \%$ for the period $2010-2013$, and $15 \%$ for the period 2014-2017.

Regarding irregularity in periods analyzed by auditing the projects included in the sample, it appears that the level of expenditure declared to the EC during the period 2007-2013 over 7 billion Euro, over 2 billion Euro are audited expenditure and total financial corrections proposed from the audit are about 63 million Euro, of which over 22 million Euro for 2013. For the period 20142017, at the level of EC declared expenditures of over 11 billion Euro, over 3 billion Euro are the audited expenditures, and the total financial corrections proposed by the audit exceed 150 million Euro, out of which over 86 million Euro belong to the year 2014. In other words, the irregularities 
found as a result of the auditing of the projects financed by the SF and the CF during the analyzed periods refer to the irregularities found in the eligibility of public procurement expenditure, as well as to irregularities related to other ineligible expenditure. The percentage of Irregularities Found (IF) in Total Irregularities (TI) over the two analyzed periods can be plotted as in Figure 2.

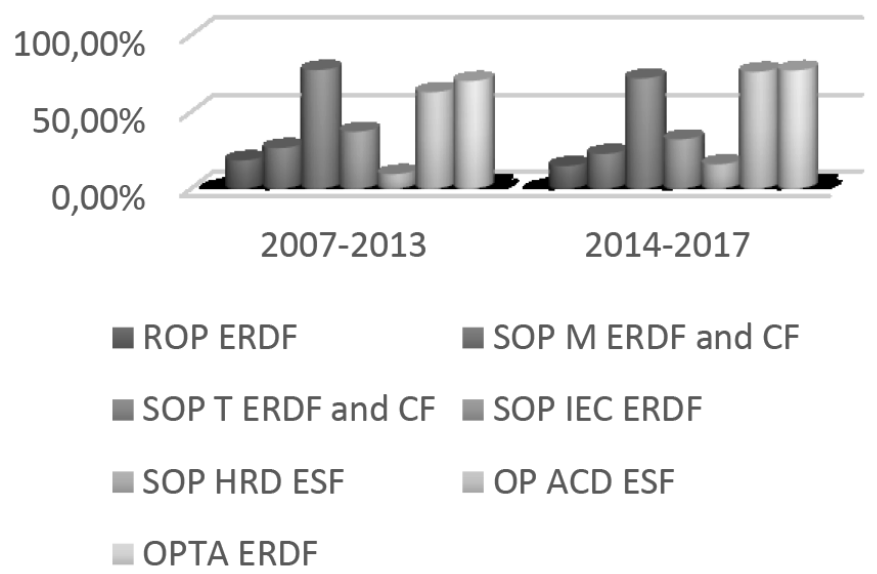

Figure 1: Share of Audited Expenses in Declared Expenses (AE/DE)

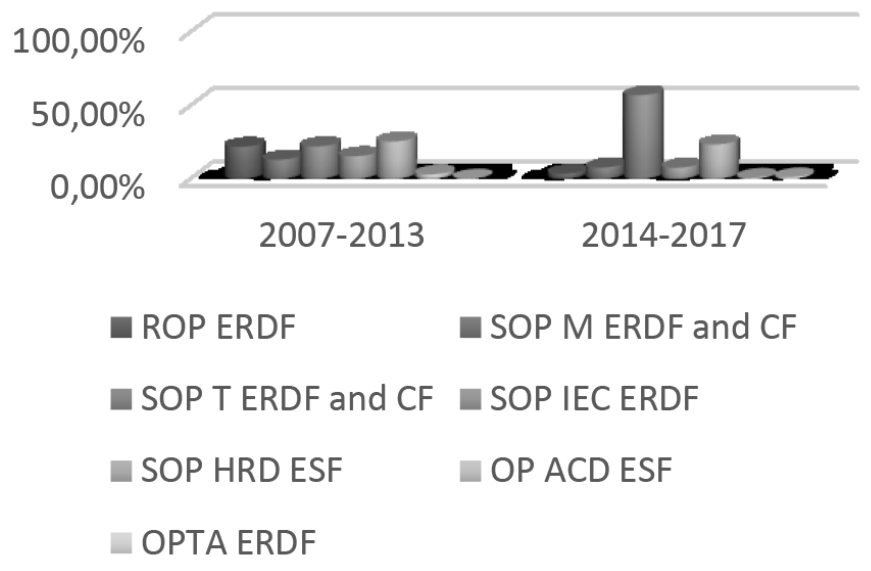

Figure 2: Share of Irregularities Found in Total Irregularities (IF/TI)

Following the audit of projects under the seven OP in the periods under review, the total financial impact of irregularities in the expenditure audited has increased considerably for projects financed from SOP T, from about $20 \%$ in $2007-2013$ to $55 \%$ in $2014-2017$. A positive aspect is noted in the case of projects financed from the ROP, where there is a decrease in the share of total irregularities found from approximately $20 \%$ in the first analyzed period to $3 \%$ in the last period, while the percentage of the expenditures audited decreased by only $4 \%$. Decreasing weightings of the observed irregularities were registered also by the projects financed from SOP M and SOP IEC. On a constant line, regarding irregularities, instead, the projects financed from SOP HRD are maintained, with $25 \%$ to $23 \%$ (decreasing), while the share of audited expenditures increased by about 6\% during the period 2014-2017 as compared to 2007-2013. The financial impact of irregularities concerning ineligible expenditure categories of irregularities (procurement and other irregularities) may be observed when considering Figures 3 and 4. 


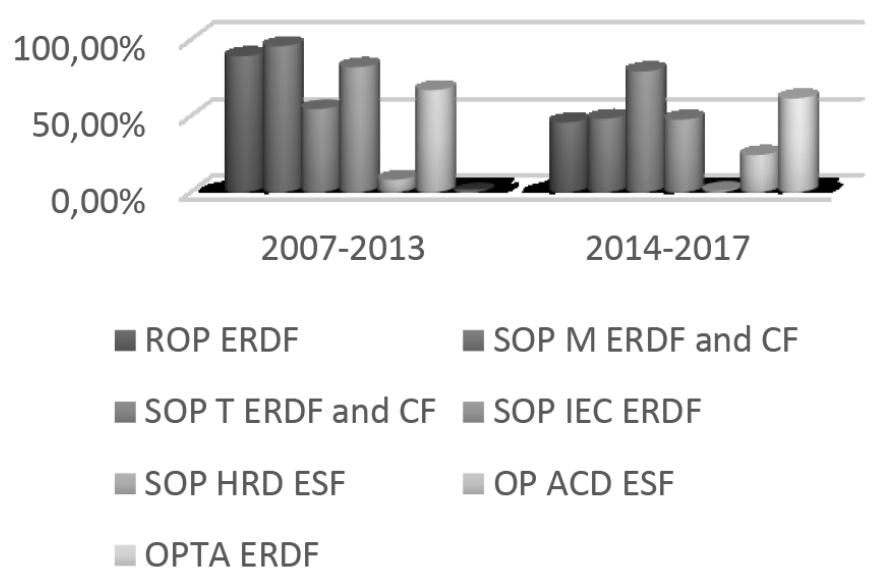

Figure 3: Share of Irregularities in Public Procurement in Total Irregularities (IPP/TI)

The financial corrections for the eligibility of public procurement expenditure for the period 20102013 amount to 37 million Euro, out of which over 10 million Euro are corrections for 2013; and all at the level of audited expenditure. For the period 2014-2017, the total financial corrections for the eligibility of public procurement expenditure exceeds 86 million Euro, out of which over 43 million Euro are in 2014. Important is that 2017 is a decrease in their reaching around 300 thousand Euro in 2017. Following the analysis of Figure 3, it is observed that for the analyzed periods there were significant increases of the public procurement irregularities for the projects financed under SOP T and OPTA, and decreases in the percentages related to the public procurement irregularities were registered as a result of the audit of the finalized projects ROP, SOP M and SOP IEC. The most frequent examples of audits of projects in the analyzed periods of irregularities related to public procurement relate to [3]: failure to comply with award procedures in the case of contracts with suppliers in the sense of non-compliance with the principle of equal treatment in the bidding process, use of the negotiated procedure without prior publication of a contract notice, modification of the information included in the contract notice without publication of a notice, etc.

Different weights than those related to public procurement have irregularities in other ineligible expenditure, as can be seen from Figure 4.

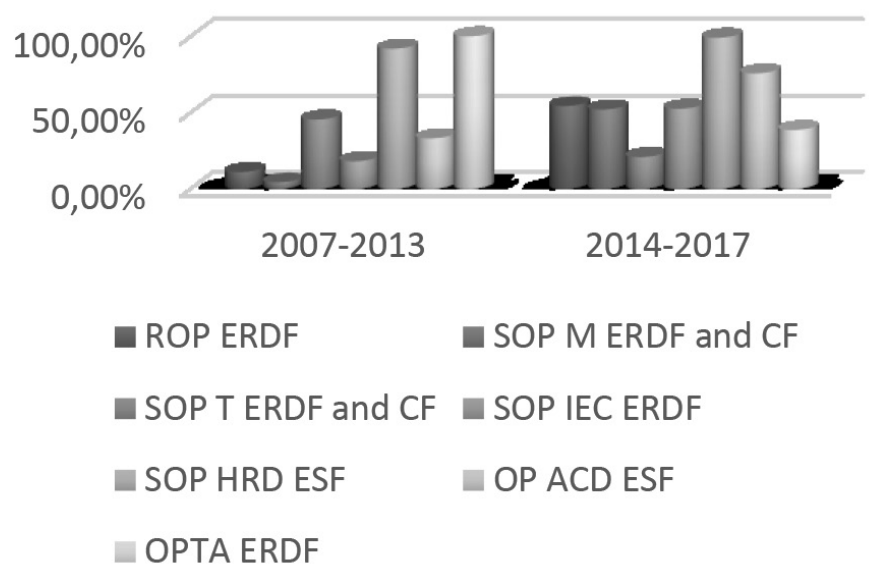

Figure 4: Share of Irregularities in Other Ineligible Expenses in Total Irregularities (IOIE/TI)

Significant weightings in the two analyzed and growing periods of these types of irregularities are found at the level of ESF-funded SOP HRD projects, followed by ACD projects funded from 
the ESF. However, there are also decreases in these types of irregularities in the case of OPTA projects, financed by the ERDF. Irregularities involving other than those ineligible for public procurement have been encountered due to the fact that various expenditures were made without complying with the financing contracts and list of eligible expenses under the legislation.

The Figure below shows that the largest share of the irregularities found in the audits of projects funded by the European funds for the two analyzed periods in the total of the audited expenditures is owned by $11 \%$ of SOP HRD projects financed by the ESF.

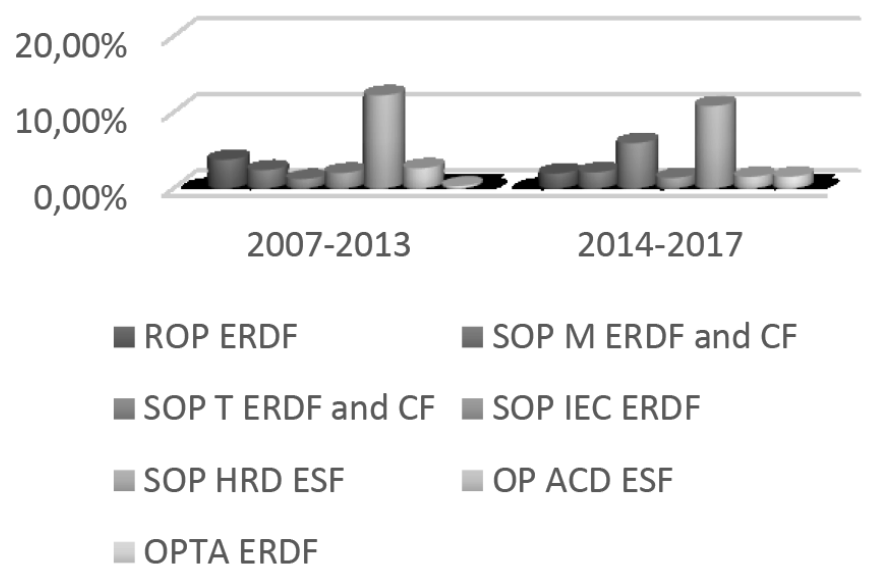

Figure 5: Share of Irregularities Found in Audited Expenses (IF/AE)

In Figure 6, it analyzes the declared expenses irregularities weight, based on the assumption that the accepted level of significance threshold is $2 \%$ of the declared expenses.

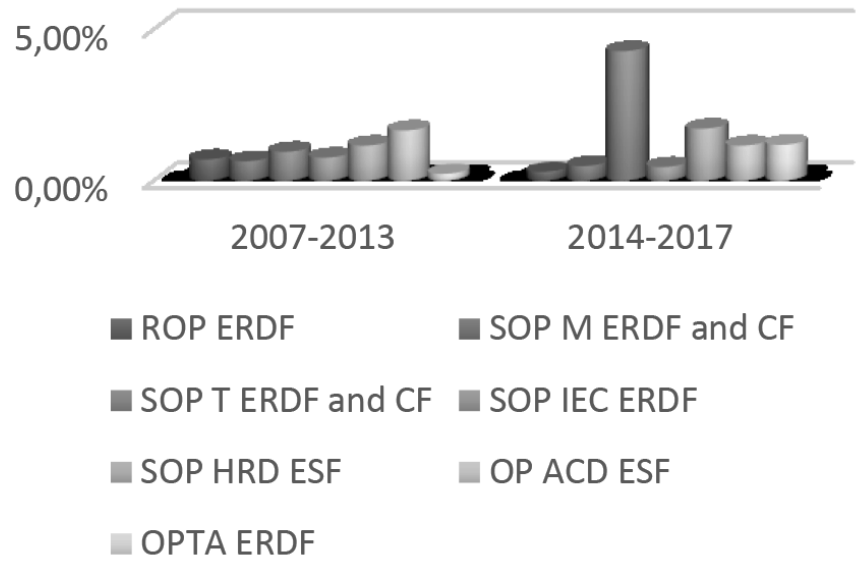

Figure 6: Share of irregularities found in declared expenses

Data analysis attached chart above, it appears that $2 \%$ is exceeded for projects related to SOP T qualifier you find in public CAR reports in this regard is "Operating system, but improvements are needed" [3].

To summarize the situation of the variables analyzed, following the Analysis of the Main Components (AMC), it can be seen from the Figure below that for the two analyzed periods, the situation of the correlations is roughly the same in the sense that a negative correlation between the observed irregularities related public procurement and detected irregularities related to other types of ineligible expenditure. 

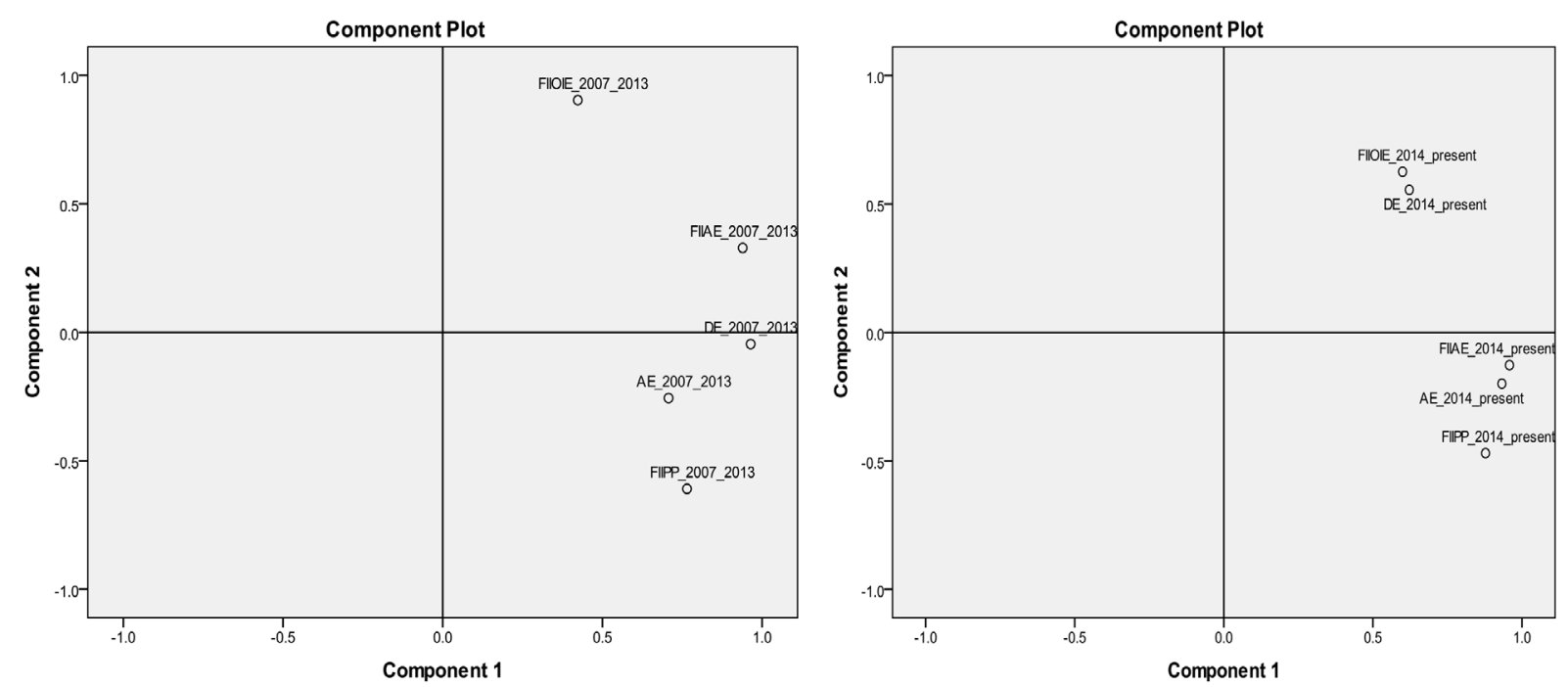

Figure 7: Correlations between variables after AMC

Instead, if we correlate the garbage in Figure 7 with Figure 8, the following findings can be made: SOP HRD, OP ACD and OPTA are characterized by the fact that on average they have the highest weights in respect of the irregularities found in other ineligible expenditure and the smallest weights, on average, related to the irregularities found in public procurement; SOP T, SOP IEC, SOP E and ROP record weights that do not differ significantly from one period to the next, except SOP T, which on average has significant weightings with respect to the total deficiencies found.

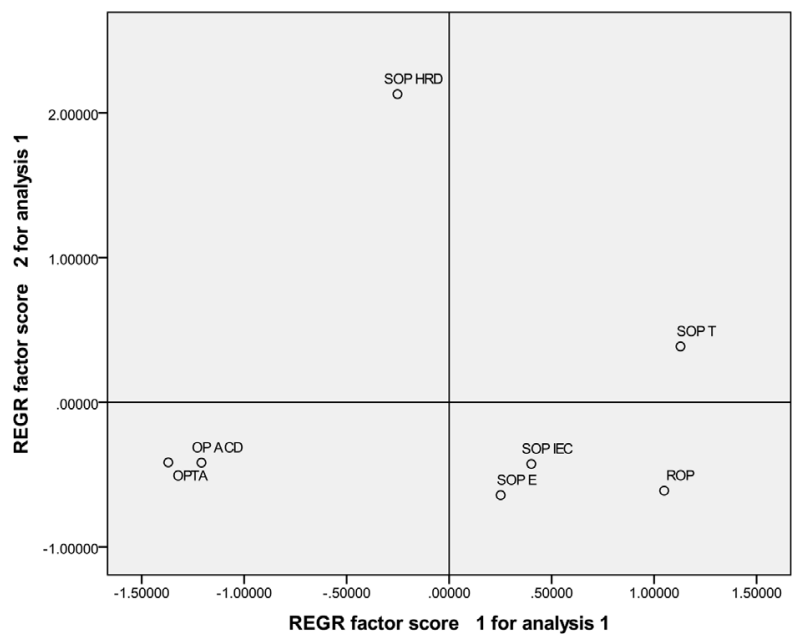

Figure 8: Similarities and differences between the OP after the AMC

This study focused on the comparative analysis of the audit results of the European projects implemented during the period 2007-2013 and from 2014 to the present, namely by the end of 2017, precisely to highlight the most important irregularities found by the auditors. The following are the most important conclusions drawn from the research.

\section{CONCLUSION}

In the present research it was desired to collect the data for project audits for the entire period 2007-2013, but the data were collected only for the 2010-2013 period since 2007 was the launch year when EC expenditure was not yet declared and in 2008 and 2009, the information was presented in the CAR reports more in a descriptive manner, without any errors. Therefore, the 
relevance of the data for the comparisons was only for the period 2010-2013. For the second 2014-2020 programming period, projects approved and funded by 2017 were considered, including the CAR Report (2018) not yet published at the time of data collection for this article. In addition, expenditure declared and audited during this period was a continuation of projects started in the period 2007-2013.

Following the processing of the data collected, it was found that the public procurement irregularities identified during the audit for the periods considered are the most frequent and, at the same time, imputed significant value corrections. As a result of the analysis of these issues on OP and periods, there was a greater share of the irregularities found in the OP in the last years of the first analyzed period (2007-2013) and in the first years of the second analyzed period (20142017). If you are considering seven OP, the highest percentage of irregularities is found for POS $\mathrm{T}$ in significant increase in the period 2014-2017 to 2010-2013. With reference to the public procurement irregularities found in the audit of European projects, it can be seen from the previous figures that on average there is a decrease in them, and those related to other non-eligible expenditures are kept on average about the same level. Instead, the share of total irregularities found in audited expenditures is maintained at a significant, very low, downward trend for SOP HRD for the two periods under review. The materiality threshold accepted for auditing European projects of $2 \%$ is exceeded, as could be seen, only for SOP T in the second programming period. Based on these findings, auditors' future projects must focus primarily on significant public procurement system when performing an audit for a project financed by grants.

The research adds to knowledge, because it can have a greater impact on applicative, but it has limitations. These are caused primarily by lack of data or presenting them in a more than satisfactory for study.

\section{REFERENCES}

[1] Chamber of Financial Auditors in Romania - CFAR, (2014a). Collaboration protocol on the organization and conduct of financial audit activity for European funds and other non-reimbursable funds from other donors (Protocol de colaborare privind organizarea și desfăşurarea activității de audit financiar pentru fonduri europene și alte fonduri nerambursabile de la alți donatori). [online] Available at: http://www.cafr.ro/uploads/Protocol\%20MFE-3454.pdf (currently abrogated) [Accessed 10.05.2019].

[2] Ministry of Regional Development, Public Administration and European Funds, (2017). Request for termination of collaboration protocol on the organization and conduct of the financial audit activity for European funds and other non-reimbursable funds from other donors. [online] Available at: https://www.cafr.ro/uploads/Rezilierea\%20Protocolului\%20 de $\% 20$ colaborare $\% 20$ CAFR $\% 20 \%$ E2\%80\%93\%20MFE-8ed3.pdf [Accessed 12.05.2019].

[3] Court of Accounts of Romania, (2014). Public Report for 2013. Bucharest: The Romanian Court of Accounts.

[4] Grosu, M., Robu, I., B., Maha, L., G. (2018), Study on the Impact of Projects from European Funds in 2007-2013 and Impact on Present and Future of Grants, International Conference on European Union Financial Regulation, "Alexandru Ioan Cuza" University Publishing House, Iasi, pp. 285-299.

[5] Kameniczki, C. (2009). Auditor's responsibility in auditing projects with domestic and international funding in Romania (Răspunderea auditorului în auditarea proiectelor cu finanțare internă și internațională în România). In: National and international financial audit activity. Auditors and the global economic crisis (Național și internațional în ac- 
tivitatea de audit financiar. Auditorii și criza economică globală), Second Congress of Financial Auditors of Romania. Bucharest: ELFI Publishing House, pp. 638-647.

[6] Chamber of Financial Auditors in Romania - CFAR, (2014b). Some clarifications on standards applicable to auditing projects funded by European funds (Unele clarificări cu privire la standardele aplicabile în auditarea proiectelor finanțate din fonduri europene). [online] Available at: http://www.cafr.ro/pagina.php?id=141 [Accessed 02.06.2019].

[7] Council Regulation (EC) no. 1083/2006 laying down general provisions on the European Regional Development Fund, the European Social Fund and the Cohesion Fund. online] Available at: http://www.fsesudest.ro/legislatie/070307r1083RO.pdf [Accessed 03.06.2019].

[8] IAASB, (2013). International Quality Control, Audit, Review, Other Insurance and Related Services (Manual de Reglementări Internaţionale de Control al Calităţii, Audit, revizuire, Alte Servicii de Asigurare și Servicii Conexe), vol. I and II, Bucharest: CFAR.

[9] Șuteu, A. (2013). Audit of European structural funds - agreed procedures (Auditul fondurilor europene structurale - proceduri convenite). Practici de audit (Audit Practices), 2(6), pp. 19-28.

[10] Staicu, E. (2014). Auditors on European funds and other non-reimbursable funds: How to obtain certification (Auditori pe fonduri europene și alte fonduri nerambursabile: Cum se obține certificarea). [online] Available at: http://legestart.ro/auditori-pe-fonduri-europene-si-alte-fonduri-nerambursabile-cum-se-obtine-certificarea/ [Accessed 20.05.2019].

[11] Șerban, M. (2014). Auditing European Funds - Comparisons between ISRS 4400 and ISA 805 (Auditarea fondurilor europene - comparații între ISRS 4400 și ISA 805). Practici de audit (Audit Practices), 3(11), pp. 13-17.

[12] Șuteu, A. (2015). Reflections on ISA 805 from the Audit of European Funds 2014-2020 (Reflecţii privind ISA 805 din perspectiva auditului fondurilor europene 2014-2020). Practici de audit (Audit Practices), 3(15), pp. 43-52.

[13] Anghelache, G., V., Anghelache, C., Anghel, M., G., Stoica, R. (2017), Elements for EU Cohesion Policy 2014-2020, Revista de Statistică, Supliment, vol 65, issue 5, pp. 77-86

[14] Hațegan, C.D. (2013). Study on the financial audit activity for the verification of European projects in Romania (Studiu privind activitatea de audit financiar pentru verificarea proiectelor europene în România). Audit Financiar (Financial Audit), Year XI, 102(6), pp. 3-10.

[15] Săvoiu, G., Bănuță, M., Gâdoiu, M. (2013), Some Accounting Issues and Statistics about Romania and EU Funds - Absorption through Projects and Eligible Expenses, revista de Statistică, INS, Bucharest, no. 1, pp. 126-136.

[16] Botez, D., (2012a). Auditor's intervention on non-reimbursable structural funds (Intervenția auditorului privind fondurile structurale nerambursabile). Studia Universitatis Petru Maior Series Oeconomica, [online] 6(1), pp. 24-38. Available at: http://oeconomica. upm.ro/OVI/24-38DanielBotez.pdf [Accessed 01.06.2019].

[17] Botez, D. (2012b). Experiences and suggestions on documenting structural fund audits (I and II), (Experiențe și sugestii privind documentarea auditării fondurilor structurale - I și II). Audit Practices, no. 3 and no. 4, pp. 21-24.

[18] Mataragiu, C., Oșanu, O., Grapini, A., C., Chereji, A., Untariu, A. (2013). Audit of Structural Funds - step by step (Auditul fondurilor structurale - pas cu pas). Bucharest: Datagroup Publishing House.

[19] Șerban, M. (2012). Audit of European projects - from theory to practice (Auditarea proiectelor europene - de la teorie la practică). Practici de audit (Audit Practices), 4 (issue), pp. 13-19.

[20] Burja, V., Jeler (Popa), I., (2018). The Control of the Implementation and Management of European Funds. Academic Journal of Economic Studies, Faculty of Finance, Banking 
and Accountancy Bucharest, „Dimitrie Cantemir” Christian University Bucharest, 4(1), pp. 89-93.

[21] Bostan, I., Grosu, V. (2010), The social effects of the current economic crisis on the European Union labour market, Revista de Cercetare și Intervenție Socială, vol. 31, pp. 7-21.

[22] Gelămancă, B., Zai, P. (2013), Abordări privind absorbția Fondurilor Structurale în România în perioada 2007-2013, Revista Transilvană de Științe Administrative 2(33), pp. 76-88.

[23] Cocoșatu, C., C. (2015), Abordare sistemică privind implementarea fondurilor externe nerambursabile in România (Systemic approach on the implementation of European grants in Romania), Academia Română, Institutul de economie Mondială, Impactul transfprmărilor socio-economice și tehnologice la nivel național, european și mondial, No. 1, vol. 1.

[24] Court of Accounts of Romania, (2010-2018). Public Report for 2008-2017. Bucharest: The Romanian Court of Accounts.

[25] Pintilescu, C. (2007), Multivariate Statistical Analysis (Analiză statistică multivariată), "Alexandru Ioan Cuza" University Publishing House, Iasi

[26] Jaba, E., Robu, I., B. (2011), Obținerea probelor de audit pentru testarea "Going Concern", folosind metode statistice avansate în analiza influenței factorilor asupra ratei îndatorării globale, Audit Financiar (Financial Audit), vol. 9, no. 81 